\title{
Leadership Emergence and Style: Fidel Castro of Cuba
}

\author{
Albert Poliquen Mbiatem*
}

\begin{abstract}
This study examines Fidel Castro's leadership emergence and style in Cuba with reference to the situation, goals sought, leadership process and the outcomes. The emergence of Fidel Castro was underpinned by the qualities he exhibited and significant popular support he enjoyed from different strata of the society. Transforming a pre-revolutionary corrupt, oppressive and discriminatory system by creating equal opportunities for everyone was the main objective of Fidel Castro's led revolution in Cuba. Despite some efforts toward societal transformation, Cubans were divided over the achievements of the revolution. While some expressed positive views about Fidel Castro's initiated socialism, others described it as a source of frustration. Findings reveal that the level of leadership effectiveness under Fidel Castro was largely attained through a variety of styles used to address different situations. The resilient abilities Fidel Castro shared with followers could enable socialist Cuba survive the Cold War and the post-Cold War eras.
\end{abstract}

\section{Introduction}

Leaders often emerge when they portray qualities appropriate to address prevailing societal challenges. The independent Cuba in Latin America witnessed a serious development crisis during the autocratic rule of Colonel Fulgencio Batista from the 1940s. This crisis was characterised by a high scale of corruption that resulted in severe socio-economic setbacks. The disenchantment of Cubans in urban and rural areas triggered popular manifestations from student movements, political alliances and the remarkable armed Cuban revolution spearheaded by Fidel Castro. The consistent revolutionary ideologies depicted by Fidel Castro from his student life, through his civilian career and armed revolution, rendered his emergence in 1959 timely as the majority of the population needed change. According to Hollander, the emergence of a charismatic leader derives from 'the need of new, revolutionary 
political systems for legitimation and for filling the gap left behind by the destruction of pre-revolutionary institutions and values'. ${ }^{1}$

Fidel Castro emerged as he inspired many Cubans with charismatic abilities to revolutionise a long time detested system. The socialist system championed by the leader assumed the responsibility to address the crisis with a directional leadership style. Although some elements of capitalism could be found especially in the sector of tourism, Fidel Castro largely used socialism as a political system to address societal issues for almost half a century. Passing through the cold war and the post-cold war, Fidel Castro's regime survived the missile crisis, the Bay of Pigs Invasion, economic sanctions, numerous coup attempts and, the collapse of the Soviet Union. The resilience displayed by Fidel Castro and his followers could enable the former to 're-emerge' when facing new situations from within or beyond national boundaries. Having demonstrated considerable leadership effectiveness in the sectors of health, education, agriculture, sports among other socio-economic related activities, Fidel Castro had however not liberalised political power.

Although Fidel Castro's leadership has extensively been examined overtime, the dynamics surrounding his leadership emergence and style remain relevant amidst increasingly diverse trends toward the study of leadership. This case study which cuts across Cold War and post-Cold War eras is presented in a context where leadership emergence and style are not only characterised by individual qualities but also by prevailing societal circumstances. The prevailing situation underpinned by socio-political and economic challenges was an entry point for leadership emergence and subsequently leadership styles in socialist Cuba. Additionally, the changing situation witnessed the 're-emergence' of a leader - Fidel Castro - compelled at times to embrace some non-socialist values. On the basis of this context, this paper mainly examines Fidel Castro's leadership emergence and style with critical assessment of the leadership process and produced outcomes.

\section{Conceptual Framework}

On a societal perspective, the emergence of leaders is largely characterised by prevailing situation or circumstances. Leadership emergence is not merely limited to the level competences of the leader but also how the leader uses such competences to influence or respond to the needs and demands of followers. Schneider and Goktepe define emergent leaders as members who exert

\footnotetext{
1 Hollander, Paul (2002), Discontents: postmodern and postcommunist (New Brunswick: Transaction Publishers), p. 379
} 
significant influence over other members of the group although no formal authority has been vested in them. ${ }^{2}$ Leaders emerge through a complex process of role taking. The most common way of assessing emergent leadership in groups has been to simply ask group members to nominate the individual(s) who they perceive to be the leader(s). ${ }^{3}$ Espousing the scenario to a broader level - the society, it is obvious to argue that, the emergence of leaders is contingent on the perceptions or needs of the followers as they fundamentally constitute the prevailing situation. As it is the case in leadership style, the emergence and re-emergence of leaders are largely determined by the situation, competences and the relationship with followers.

Leadership style is generally observed via three models - subjective, situational and relational. ${ }^{4}$ Although charisma based on personal traits has extensively been used by a considerable number of authors to describe Castro's leadership, the combination subjective, situational and relational remains fundamental in assessing the latter's leadership in Cuba. Subjective perspective refers to the Great Man theory by projecting the biographies of stupendous men. ${ }^{5}$ The situational approach which gained immense attention among researchers in the mid-20th century is context and time specific with focus on surrounding factors. ${ }^{6}$ The situation is the entry point which determines the qualities required from the leader and how he is expected to interact with followers. The relational approach presents leadership as a process underpinned by the relations between the leaders and the followers. On this interactive approach Burns sees leadership as collective and purposeful. ${ }^{7}$ One of the peculiarities of Fidel Castro's leadership is based on the fact that it could combine to a considerable extent the subjective, situational and relational models. Although Fidel Castro has extensively used personal qualities in the course of his leadership, he was also very concerned with the nature of relationship shared with followers and the importance of leading according to the situation or circumstances.

\footnotetext{
2 Schneider, Ehrhart and Goktepe, Janet (1983), 'Issues in emergent leadership: The contingency model of leadership, leader sex, leader behavior'. In H. H. Blumberg, A. P.Hare, V. Kent, \& M. F. Davies, eds., Small groups and social interaction (Chicester, England: John Wiley), pp. 414-418

3 Balthazard, Pierre; Waldman, David and Warren, John (2009), 'Predictors of the Emergence of Transformational Leadership in Virtual Decision Teams'. The Leadership Quarterly Vol. 20, p. 652

4 Turska-Kawa, Agnieszka (2013), 'Reactive Political leadership'. Political Preferences, No 4/2013, University of Selesia, Poland, p. 115

5 Bennett, William (2011), The Book of Man: Readings on the Path to Manhood (Nashville TN: Thomas Nelson Publishers), p. 396

${ }^{6}$ Sternberg Robert, Antonakis John and Cianciolo Anna (2004), The Nature of Leadership (Thousand Oaks, CA: SAGE), p. 148

${ }^{7}$ Burns, James (1978), Leadership (Harper \& Row, Publishers), p. 18.
} 


\section{Situation and Leadership Emergence}

The statist and corporatist policies of President Batista failed to be effective in a corrupt system reflected by an advanced degree of bribery and embezzlement. ${ }^{8}$ During the rule of president Batista, there was a huge socio-economic gap between self-interested politicians and ordinary Cubans. The key issues involved were: corruption, lack of accountability, no freedom of press and speech, political oppression, illiteracy, inadequate access to health facilities and 'petite bourgeoisie' based on exploitative ideologies. ${ }^{9}$ These vices affected the society negatively causing economic regression and poor standard of living among the ordinary citizens. The Cuban1940 Constitution was suspended and most socio-political rights cancelled including the right to strike. With the conspiracy of some wealthiest sugar plantation owners, Batista continued to preside over a stagnating economy. ${ }^{10}$ The precarious situation under Batista's oppressive rule led to increasing popular demands as people were seeking range of goals for congruous development.

In this context, the main goals sought by the society were the following: (a) Creation of equal opportunities for income generation in the society irrespective of any background; (b) establishment of a sovereign Cuban state by terminating the era of imperialism (the United States' domination); (c) access to appropriate health care and education; (d) respect of human rights and general political participation; (e) human building capacity for sustainable economic development and (f) improvement in general standard of living and appropriate governance to address the crisis. ${ }^{11}$ 'The necessity of the Revolution in historical terms arises from what could be defined as the four great national aspirations that were frustrated from the 19th century onwards: national sovereignty, social justice, sustainable economic development and democratic selfgovernment'.12 With the aim to achieve the aforementioned sought goals, student movements, opposition alliances and armed struggle in Cuba set a path for leadership emergence.

Cubans felt an urgent need for a new leader capable of altering the precarious socio-economic and repressive political system put in place by Batista over the

\footnotetext{
${ }^{8}$ Carbonell, Brenden (2009), 'Cuban Corporatism: Batista's Three-year Plan and a Nation Betrayed in eds cuba in transition'. ASCE 2009. p. 275

9 Dominguez, Jorge (1998), 'Batista in Cuba' in Chehabi, H. and linz, J., eds Sultanistic Regimes (The Johns Hopkins University Press), pp. 120-128

10 Olson, James (2000), Historical Dictionary of the 1950s (Greenwood Publishing Group), p. 67

11 Castro, Fidel (1953), 'History Will Absolve Me'. Excerpts from his own defense, delivered at his trial, October 1953, pp. 1-5

12 Treto, Carlos (2009), 'Continuity and political change in Cuba'. University of Havana, p. 6
} 
years. Protests against Batista's repressive rule were carried out by university of Havana students' body - 'Federación Estudiantil Universitaria' (FEU) in which Fidel Castro took part from 1945 to 1950. The FEU also witnessed the emergence of a charismatic leader José Antonio Echevarría, who led a courageous students' attack over the presidential palace in 1957 where he lost his life. Years before, a university lecturer Rafael García Bárcena, strongly represented the National Revolutionary Movement (MNR) that regrouped students in 1953 to protest against Batista's regime. ${ }^{13}$ Fidel Castro's emergence went through different stages: civilian politics in 1952; failed coup and imprisonment in 1953; amnesty and release in 1954; armed revolution in 1956 and power accession in 1959.

Fidel Castro's defence speech and imprisonment as a result of the failed and risky Moncada attack in 1953 was very crucial for his political emergence. Having taken his own defense in court on October 16, 1953, Castro denounced the controversial policies of the government. He went on to speak of '700,000 Cubans without work', criticised the healthcare and schooling system, and asserted that $30 \%$ of Cuba's farm people couldn't even write their own names. ${ }^{14}$ Whilst in prison, Castro gained more popularity as he released the manuscript of his revolutionary memorandum titled 'history will absolve me'. The communication Castro engaged with Cubans from his prison cell made of him a potential leader of a revolution against the despotic regime of Batista. The published manifesto based on Castro's defence speech mainly outlined five revolutionary laws. ${ }^{15}$ (a)The reinstatement of the 1940 Cuban constitution; (b) the reformation of land rights; (c) the right of industrial workers to a 30\% share of company profits; (d) the right of sugar workers to receive 55\% of company profits and (e) the confiscation of holdings of those found guilty of fraud under previous administrative powers. ${ }^{16}$ On release from prison, Fidel Castro continued to demonstrate revolutionary qualities.

Some qualities which Bernard Bass identifies in his work on leadership could also be identified in Fidel Castro: stature, fluency of speech, knowledge, insight, initiative, persistence, ambition and industry. ${ }^{17}$ In order to overthrow the increasingly unpopular government of Batista, the idea of a revolution that would promote equality among Cubans became a strong platform of Castro's armed struggle. Generally, some requirements for successful revolution present

\footnotetext{
13 Slee, Chris (2008), Cuba: How the Workers and Peasants Made the Revolution (Resistance Books Australia), p. 10

${ }^{14}$ Hugh, Thomas (1986), The Cuban Revolution (Weidenfeld and Nicolson. London), p. 64

15 Ibid, p. 170

${ }^{16}$ Castro (1953), p. 5

17 Bass, Bernard (2008), The Bass Handbook of Leadership. Theory, Research, and Managerial Applications. Fourth Edition. (Free Press), pp. 84-87
} 
leaders as fully dedicated to the cause and able to exhibit that devotion by going through all the challenges or consequences of the revolution. Such leaders risk their lives; undergo imprisonment, exile, maltreatment and frequent hardship. Fidel Castro and his companions experienced most of these aforementioned sufferings. Revolutions often underpinned by martyrdom must survive all defeats and setbacks with the ultimate objective to effectively address societal wants, needs and aspirations. They thus portray a vigorous sense of mission, of end values and of surpassing purpose. ${ }^{18}$ The Cuban revolution encompassed most of the requirements for a potential success.

With wisdom, courage and determination, Fidel Castro strongly believed the revolution will emerge from the mountains. ${ }^{19}$ Moreover, he was not discouraged after the regular army's ambush that led to the blatant loss of most his armed men on their way to the 'Sierra Maestra' mountains. The courage and determination of the leaders were strong inspiring factors for followers which continued to believe in a potential victory. In his writings, Che Guevara, one of Fidel Castro's loyal collaborators finally acknowledged the wisdom and the foresight of Fidel Castro, although they both disagreed repeatedly on some battle tactics while in the mountains. ${ }^{20}$ As a leader, Fidel Castro emerged in a group (the rebellion at the 'Sierra Maestra' mountains) and the society as a whole where he increasingly received support from many less privileged Cubans. This form of popular legitimacy was sustained the more by Fidel Castro's outstanding communication ability.

Communication, a key factor in the success of the revolution was used to propagate series of victories against the regular army and most importantly appeal for more popular support from rural and urban areas. Radio Rebelde was used by the Guerilla as the main channel of disseminating information to the people. From February 1958, information concerning battles were broadcasted twice in the evening. ${ }^{21}$ On Fidel Castro's communication abilities, Delgado attributes to the former rhetorical qualities. Through his analysis made on Fidel Castro's speech - 'Words to the Intellectuals' - Delgado makes out Fidel Castro's recurrent use of ideographs to create a common revolutionary front for Cubans. ${ }^{22}$ Castro's epideictic rhetoric skills were observed in the courts, in preparation for legislative deliberations and ceremonial speeches aiming to

\footnotetext{
18 Burns (1978), p. 202

${ }^{19}$ Kice, Brent (2008), 'From the Mountains to the Podium: the Rhetoric of Fidel Castro'. PhD Thesis Submitted to the Louisiana State University, p. 20

20 Guevara, Ernest (2006), Reminiscences of the Cuban Revolutionary War (Harper Perennial), pp. 77-111

${ }^{21}$ Martin, Lionel (1978), The Early Fidel: Roots of Castro's Communism. Secaucus (NJ: Lyle Stuart), p. 227.

22 Delgado, Fernando (1999), 'The Rhetoric of Fidel Castro: Ideographs in the Service of Revolutionaries', Howard Journal of Communication Vol.10 pp. 1-14
} 
create a sense of revolutionary mindset and unity among Cubans. ${ }^{23}$ The leadership emergence of Fidel Castro was thus largely backed by his rhetorical communication abilities intended to align Cubans towards a common line of thought.

Whilst the repression of Batista's government over urban contestations was intended to weaken protesters, it however created an avenue for a common revolutionary front as armed and civilian movement decided to form an alliance. Previous disagreements between the mountain guerrilla fighters of Fidel Castro and urban fighters of the 'Llano' movement were settled in a meeting in the 'Sierra Maestra' aiming at reorganising the revolution. Therefore, on May 3, 1958 Fidel Castro virtually took full control of the revolution. ${ }^{24}$ From the mountains, the revolution of Fidel Castro enjoyed a popular legitimacy from urban and rural residents who were increasingly ready to join the 'Sierra Maestra' fighters. The revolutionary ideologies prone by Fidel Castro and his collaborators were welcomed amongst the people who have for several decades suffered under an exploitative capitalist system. Although some psychological elements of leadership could be perceived from the traits or qualities of Fidel Castro, the sociological or contextual aspect was also very essential to the emergence of the former. Moreover, it is imperative to note that the emergence of Fidel Castro did not take place in solitude but with the hefty support of his collaborators or comrades who also emerged in different capacities. Among his collaborators, the emergence of Che Guevara, Celia Sanchez and Raoul Castro was remarkable.

Moreso, the emergence of Fidel Castro was however strongly consolidated by his alignment to the philosophy of Jose Marti - the father of the nation who led the struggle of Cuba's independence. Fidel Castro did not only use his rhetorical skills for simple communication purpose. His rhetorical skills were also used to attach his relatively similar biography to that of Jose Marti the Cuba's first heroic figure. ${ }^{25}$ His attachment to the image and ideologies of Jose Marti granted him extensive legitimacy among Cubans and prepared a more or less smooth ground for his leadership. Thereby, Fidel Castro enjoyed huge support among his collaborators and many Cuban who were convinced of the determination of the new leader to redeem the society from nest of political and imperialist exploitation. Castro's emergence at the helm of the Cuban state was largely situational as he portrayed some leadership qualities required to lead Cuba

\footnotetext{
${ }^{23}$ Kice, Brent (2008), 'From the Mountains to the Podium: the Rhetoric of Fidel Castro'. PhD Thesis Submitted to the Louisiana State University, p.1 6

${ }^{24}$ Guevara (2006), pp. 252-259

25 Rice, Donald (1987) 'Castro's Early Rhetoric: The Myth of the Savior' in Charles Kneupper, ed, Visions of Rhetoric: History, Theory and Criticism (Arlington, TX: Rhetoric Society of America)
} 
during the post-Batista era. As the strong desire for change emanated from a large part of the population, the emergence of Fidel Castro's gained more grounds.

Having emerged in the late 1950s, Fidel Castro was not too clear on his political ideology. Barely two years following his accession to power and the unsmooth relationship with the West (especially the US) Fidel Castro must have gotten no choice than to declare Cuba a socialist state. Having been led through a socialist perspective for over four decades, Cubans witnessed directional approach and power centralization in the socio-political and economic constructs. Although personal traits were extensively observed under Fidel Castro's leadership, the relational aspect was however not undermined.

\section{Fidel Castro's Leadership Style in Cuba}

Leaders often tend to define the situation and set a way forward. They legitimise their actions on the basis of their persuasive account of the situation. As a result of such behaviours, the social construction of the problem legitimizes the deployment of a particular form of authority. ${ }^{26}$ In Cuba, the authority depicted by Fidel Castro had adopted various forms at different stages of his leadership. The latter's leadership exhibited personal qualities, relational abilities and resilience towards prevailing situations.

\section{Personal Traits and Charisma}

Fidel Castro emerged in 1959 as the new leader of the Cuban state and was considered by many Cubans (especially Cubans frustrated by Batista's regime) as the ideal person to address the situation. During Fidel Castro's first televised speech in January 1959, a white dove landed on his shoulder and another one perched upon the podium. Both doves stayed in their respective positions till the end of the allocution. The appearance of the doves became a serious point of discussion. Although the international press described the spectacle as a strange accident involving 'doves of peace', many Cubans on the basis of their religious or cultural inclinations believed Fidel Castro was chosen by supernatural forces to lead Cuba with the required qualities. ${ }^{27}$ More so, the personal traits Fidel Castro earlier exhibited whilst in the 'Sierra Maestra' continued to gain popular legitimacy in the management of public affairs.

\footnotetext{
${ }^{26}$ Grint, Keith (2010), Leadership: A Very Short Introduction (Oxford University Press Inc., New York), p. 19

27 Miller, Ivor (2000), 'Religious Symbolism in Cuban Political Performance'. The Drama Review, Volume 44, Number 2 (T 166), Summer2000, p. 30
} 
As described by Weber, Charismatic leaders often explain their emergence as a form of destiny. 'Charismatic belief revolutionises men 'from within' and shapes material and social conditions according to its revolutionary will'. ${ }^{28}$ Although Charismatic leaders are viewed by Weber as exceptional mobilisers, they were not only revolutionary. Thus they could be both revolutionary and reactionary by trying to regain the past in order to proceeding to a new future. ${ }^{29}$ Fidel Castro had the aptitude of regaining the past in order to effect change in the society as he strove to align his ideologies to that of the positive ideas of the 'father of the nation' - José Martí. Trust, charisma, communication, determination, courage, mobilisation persuasion and tolerance were useful because most Cubans had not fully recovered from the tyrannical rule of Batista. Although Fidel Castro demonstrated some of these qualities, he could not tolerate views contrary to that of the revolution.

Under the banner of the Revolution, leadership revolved around an individual (Fidel Castro) who seemed to have answers to people's preoccupations. He was persistently aligning the people towards the idea of socialism with the state at the service of its citizens at all the levels. ${ }^{30}$ The commitment and the focus of the leader in the leadership process at almost all levels of task execution gave credibility to his vision. But along the line some Cubans became reluctant to adhere to the vision because of the considerable degree of sacrifices attached to it. 'Over the years, Fidel Castro, has based the legitimacy of his regime on the moral obligation to liberate and protect Cubans not only from oppressive imperialist forces, but also from domestic enemies of the revolution'.31 The directional leadership style of the leader did not concede ideologies radical to that of the socialist revolution. Thus, those barring the way to socialist evolution were tagged enemies; exile, imprisonment or execution could proportionally serve as punishment.

The directional approach adopted by the leader of the Cuban revolution significantly limited the possibility of power delegation. Leadership in this context often revolved around personal traits. As argued by Alfonso, there has been a gross reluctance in decentralising power to local government. He further argued that, despite some modifications in the Cuba's system of local government, the prevailing centrally planned development strategy has not

\footnotetext{
28 Weber, Max (1978), Economy and Society (Berkeley: University of California Press), p.116

${ }^{29}$ Ibid, pp. $115-120$

${ }^{30}$ Kice (2008), p. 55

${ }^{31}$ Mitchell, Orenstein (2009)'.Cuban Political System: More than Just Castro'. Comparative National Systems, p. 2
} 
been effective in addressing socio-economic challenges. ${ }^{32}$ Moreover, the nature of relations between leaders and followers under the regime of Fidel Castro reflected the type of political system that did not facilitate political leadership emergence among those who fail to align with socialist ideologies.

In Cuba, the 1976 Constitution came into existence to underpin the socialist principles championed by the leader and his dominant communist party. In its preamble it is stated that Cubans should be guided 'by the ideology of José Martí, and the sociopolitical ideas of Marx, Engels, and Lenin'. Furthermore, article 10 of the Constitution stipulates that:

'All the organs of the State, their directors, functionaries and employees, operate within the limits of their respective authority, and are obliged to strictly observe socialist legality, and to ensure respect for it in the life of the entire society'. ${ }^{33}$

Despite the existence of the constitution, and state institutions, leadership was still significantly characterised by individual traits as Fidel Castro and his close collaborators considerably influenced institutional settings. Thus Fidel Castro was a practical guide beside the official guide (Constitution). Fidel Castro is mentioned in the preamble of the 1976 constitution as the architect of full national independence, democratic changes, socialism in view of the setting up of a communist society. ${ }^{34}$ Article 5 of the same constitution describes the communist party headed by Fidel Castro as 'the superior leading force of the society and the state, organizing and guiding the common efforts aimed the highest goals of the construction of socialism and advancement toward the communist society'. ${ }^{35}$

The 1976 Constitution, established after 17 years of Castro's rule, was not only a form of superior law of the state on which Cubans ought to rely in executing their citizen rights and obligations. But the establishment of this constitution was purposefully to create a sense of awareness about an ultimate construction of a communist state that would not tolerate any type of rebellion. Article 3 of the same constitution stipulates that: 'All citizens have the right to fight, using all means, including armed struggle, when no other recourse is possible, against anyone attempting to overthrow the political, social, and economic order

\footnotetext{
32 Alfonso, Haroldo (2001), 'Local Government and Economic and Social Change in Cuba'.

Focal Research Forum on Cuba., p. 1

33 The Cuban Constitution1976, Art 10

${ }^{34} \mathrm{Ibid}$, The Preamble

35 Ibid, Art 5
} 
established by this Constitution'. ${ }^{36}$ The 1976 constitution has been a key protective tool to the regime of Fidel Castro who was bent in perpetuating socialist doctrine across the entire nation. It also played a supportive role by projecting the image of Fidel Castro as the guardian of socialist principles necessary for attaining a collective goal. Fidel Castro's charismatic and rhetorical aptitudes were also instrumental in solidifying relations with ordinary Cubans.

\section{The Relational Aspect of Castro's Leadership}

The developmental crisis in Cuba required a leader who could regularly interact with followers in order to effectively respond to multiple societal demands. In promoting socialist ideologies, Fidel Castro could often move toward the people to get feedback and in return mobilise them towards a collective goal. 'The actual 'supply' of leadership is driven by a pre-existing societal 'demand', which the political entrepreneurship of a would-be leader seeks to satisfy'. ${ }^{37}$ Leaders interpret problems, recommend approach to solve them; transmit personal visions as solutions and thus mobilise followers to implement those solutions. A significant number of scholars in the line with Macgregor Burns (1978) and Bernard Bass (1990) view leadership as a dynamic, open social system, a coherent process, rather than just a number of sporadic individual acts. Cubans needed a leader with whom they will exchange influence and the same time a conscious leader capable of addressing corruption and external exploitation among other vices. Most of these vices were seriously addressed under the leadership of Fidel Castro. The exchange of influence between the leader and followers was existent though to a certain extent. The socialist principles implemented under Fidel Castro's rule bore both transformational and transactional facets.

As perceived by Northouse, transactional leadership refers to the exchange between leaders and their followers. The nature of the exchange is 'behave as such and be rewarded accordingly'. Fidel Castro instructed his followers to abide by socialist principles and be rewarded on the basis of their efforts. On the other hand, Transformational leadership is the process whereby the leader creates a connection with followers that raises a collective level of motivation

\footnotetext{
36 Ibid, Art 3

37 Masciulli, Joseph, Molchanov, Mikhail. and Knight, Andy (2009), 'Political Leadership in Context, in J. Masciulli, M. Molchanov and W. Knight, eds., The Ashgate Research Companion to Political Leadership (Ashgate Publishing Limited, England), p. 7
} 
and morality. This type of leader is attentive to the needs of the followers and thus tries to set up a platform for followers to reach their fullest potential. ${ }^{38}$ Although very less observed in Fidel Castro's political leadership - mainly characterised by a directional model - the transformational facet was socially significant. As discussed by Burns, revolution is an entire alteration of the whole social system. It means the emergence of a radical new ideology bent to discard the previous established system. But he further posits that, 'the pure form of revolution is rare in practice'. ${ }^{39}$ In the Cuban case, transformation was mostly observed at social and structural levels. The health, education, agriculture and sport sectors were key examples of transformation by the socialist system. Meanwhile at the political level authoritarianism persisted as leaders-followers relations were more transactional.

To gain popular legitimacy, Fidel Castro tried to implement the socialist ideologies he had rhetorically been preaching to the people. The agricultural reform act of 1959 reduced the size of most farm holdings to 1,000 acres and below. This measure put an end to the largest holdings, including U.S.-owned sugar properties, several of which exceeded 400,000 acres. ${ }^{40}$ Support of the revolution increased throughout the country as lands were distributed to thousands of rural workers. Large farms became controlled by the government. $15 \%$ of owners' revenue was transferred to wage workers and peasants in accordance with the Rent Reduction Act. The government also embarked on a literacy campaign with the construction of new schools and trained thousands of additional teachers. Health care extended to all the segments of the society with the establishment of rural clinics and hospital. ${ }^{41}$ The policies such as education and health for all, nationalisation of foreign companies fight against corruption and promotion of agriculture created a massive mobilisation around the ideas of the leader in the 1960s. These measures also served to identify the movement's 'political enemies', who exposed themselves through their vociferous opposition to the changes.

Moreover, Fidel Castro tried to create relations and consolidate the legitimacy of his government inside and outside of Cuba by travelling around the American continents. After the April 1959 visit to the United States, ${ }^{42}$ Fidel Castro

\footnotetext{
38 Northouse, Peter (2013), Leadership: Theory and Practice. Sixth Edition (Sage Publication), p. 186

${ }^{39}$ Burns (1978), p. 202

${ }^{40}$ Quirk, Robert (1993), Fidel Castro (New York and London: W.W. Norton \& Company), p. 280

41 Prevost, Gary (2007), 'Fidel Castro and the Cuban Revolution'. Headwaters: The Faculty Journal of the College of Saint Benedict and Saint John's University: Vol. 24, p. 22

${ }^{42}$ Bourne, Peter (1986), Fidel: A Biography of Fidel Castro (New York City: Dodd, Mead \& Company), pp. 174-177
} 
proceeded to Canada, Trinidad, Brazil, Uruguay and Argentina where he attended an economic conference in Buenos Aires, with an unsuccessful proposal of $\$ 30$ billion U.S.-funded 'Marshall Plan' for Latin America. ${ }^{43}$ Fidel Castro used radio and television to develop a 'dialogue with the people', posing questions and making provocative statements. ${ }^{44}$ His regime remained popular with workers, peasants, and students, who constituted the majority of the country's population. ${ }^{45}$

Opposing views to the revolution mostly emanated from the middle class; thousands of doctors, engineers and other professionals migrated to Florida in the U.S., causing an economic brain drain. ${ }^{46}$ Although having some strained relations with some segments of the Cuban population, Fidel Castro could use situation of crisis to mobilise many followers and subsequently acquire more popularity. In Reaction to the Bay of Pigs Invasion, Fidel Castro stated that: 'What the imperialists cannot forgive us is that we have made a Socialist revolution under their noses'.47 By so saying he proclaimed Cuba as a socialist state for the first time in 1961. This second victory over the 'invaders' barely two years after acceding to power rendered him more popular among many Cubans who continue to consider him as the 'man of the situation'. Castro persistently appealed to the people as he could at times attribute revolutionary successes to collective efforts.

The particular interest of the revolutionary government in restructuring the sporting sector was significant in mobilising many young Cubans who did not have opportunities to practice disciplines of their choice in the prerevolutionary era. While denouncing the controversial role of sports in prerevolutionary society, leaders of the revolution called for the annihilation of old capitalist attitudes towards sport in Cuba. ${ }^{48}$ This concern for sport was not simply connected to Castro's natural inclination to sports as he loved practicing Basket ball and base ball games. Fidel Castro blamed the capitalist system to be at the origin of the recurrent poor performance of pre-revolutionary Cuba in international competitions as he declared: 'At the Olympics, it was shameful to see the position occupied by Cuba because the rich accustomed to good living had not the necessary spirit of sacrifice to be good athletes'. And he concluded, 'good athletes must come from the...working classes, from lower strata because

\footnotetext{
43 Ibid, p. 177

${ }^{44}$ Ibid, p. 179

45 Coltman, Leycester (2003), The Real Fidel Castro (New Haven and London: Yale University Press), p. 168

46 Ibid, p. 167

47 Quirk (1993), p. 369

${ }^{48}$ Bunck, Julie (1994), Fidel Castro and the Quest for a Revolutionary Culture in Cuba (The Pennsylvania State University Press), p. 190
} 
they are capable of sacrifice'. ${ }^{49}$ The socialist leader could also easily use any form of achievements for political recuperation.

The interactions between leaders and followers continued throughout the 1970s and 1980s as socialism required collective efforts to achieve the social and economic set goals. The fluctuating Cuban economy and the massive emigration by significant number of Cubans to the U.S and other countries ${ }^{50}$ were instigating factors for Fidel Castro to enhance the interactions with followers. Castro was bent in increasing the interaction with the followers. He listed in his April 1981 speech the achievements of socialism in Cuba: 'Socialism has sown schools, technological institutes, universities in our own country. Socialism brought us into first place in Latin America in the field of education'. ${ }^{5}$ He was thus able to initiate a form of dialogue with the people by defending the achievements of his government. Whether or not Castro genuinely sought to prioritise collective over personal interests, he had always understood the key role of followers in the leadership process. The international political and economic order was however determinant in Fidel Castro's leadership in Cuba. While socialist Cuba was demonized in the West, it was however praised in a good number of developing societies.

\section{Cuba on the International Scene}

The socialist ideology depicted by Fidel Castro made of Cuba a point of international attraction as Russia and the United States (US) could see their respective interests clashed at the midst of the cold war era. Castro's regime supported by Russia was able to crush the rebellion (the pigs of bay invasion) backed by the U.S in the 1960s. According to the New York Times, one of the conditions for the removal of missiles by Russia was the non invasion of Cuba by the U.S. ${ }^{52}$ The effectiveness and outcomes of Castro's rule over Cuba has to a large extent been determined by the country's foreign policies and the type relationship it shared with different countries across the globe. Cuba's relations with United States under the rule of Fidel Castro were not smooth. Despite the perennial condemnation of successive U.S presidents of the Cuban political system, Fidel Castro succeeded to outlived 10 U.S presidents and 16 Central Intelligence Agency (CIA) directors. 'An unusual individual with an eidetic

\footnotetext{
${ }^{49}$ Pickering, Ron (1978), 'Cuba' in Sport Under Communism Ed. James Riordan (London: C Hurst \& Co.), p. 149

50 Ojito, Mirta (2005), Finding Manana: A Memoir of a Cuban Exodus (NY: Penguin), pp. 7793

${ }^{51}$ Castro, Fidel (1981), 'Defending Cuba's Socialist Revolution'. Fidel Castro Speeches. Vol.

2. Ed. Michael Taber (New York: Pathfinder) , p. 325

52 New York Times (1962) 'Letter from President Kennedy to Chairman Kruschev'. Oct 27, p. 30
} 
memory, Castro is totally narcissistic but able to learn new tricks and teach old ones'.53 In the same vein, Latell earlier stated that:

Since the dawning of his political career in the late 1940s Fidel Castro has demonstrated exceptional, often remarkable leadership qualities. Few of them would be considered admirable in a democratic society or ethical by any standard, but they have been critical to his success in holding on to power for more than 47 years. ${ }^{54}$

As a result of Fidel Castro's unfriendliness with the western world, notably the U.S, Cuba suffered from U.S economic sanctions and other forms of isolation. This situation to a large extent continued to fuel the determination of the Cuba political leadership to go beyond national boundaries and exhibit its socialist ideologies. In addition to the good relations shared with many South American states, Cuba also maintained positive relations with some African states. Projecting itself as the advocate of victims of imperialism, Cuba's involvement in Africa has been very crucial to its international achievements.

From the early 1960s, Cuba began its intervention via medical or military support in Algeria, Congo, Guinea and Ghana among others. 55 The 1975 military intervention particularly in Angola made of Cuba a noticeable actor in the Cold War era. 56 The large scale of Cuban intervention in Angola was described by many as an effective fight against apartheid in South Africa, as South African soldiers were involved in the Angolan war. As a result, independent South Africa has remained very grateful to Cuba through the words of its liberation fighter, Nelson Mandela. The latter said: 'What Fidel Castro has done for us is difficult to describe with words... First in the struggle against Apartheid he did not hesitate to give us all his help and now that we are free we have many Cuban doctors working here'. ${ }^{57}$

Grint emphasises on the necessity of interactions between leaders and followers with the competence or quality of the leader appropriate to the context. A competence might be necessary in a context and unnecessary in another one.

\footnotetext{
53 Wong-Dias, Francisco (2006). 'Castro's Cuba: Quo Vadis'. Strategic Studies Institute (SSI) Publications, p. 1

${ }^{54}$ Latell, Brian (2006), 'Fidel Castro and the Media'. The Latell Report, Cuba Transition Project (CTP) at the University of Miami's Institute for Cuban and Cuban-American Studies (ICCAS), May 2006, p. 1

55 Kessler, Stephanie (1990), 'Cuba's Involvement in Angola and Ethiopia: A Question of Autonomy in Relationship with the Soviet Union'. Thesis, December 1990. Naval Postgraduate School Monterey, California, p. 34-35

56 Ibid, p. 1

57 The Huffington Post (2013). 'Nelson Mandela, Fidel Castro: A Relationship Built On Mutual Admiration'. By Hirania Luzardo, June 27, 2013, p. 1
} 
Thus, it is important to consider what leaders 'do' rather than what they 'have'. ${ }^{58}$ Do leaders' acts respond to the situation at hands? In Addition to relative tough time witnessed during the cold war era, a new situation in post 1990s (end of the cold war) required a form of leadership re-emergence.

\section{A New Situation: Leadership Resilience}

The end of the Cold War and consequently the collapse of the Soviet Union in 1990 had led to the fall of many communist regimes in Eastern Europe, South America and other parts of the world. The Cuban regime was then facing a serious crisis as its main ally (the Soviet Union) was losing control over its own region. The Challenges to Fidel Castro's regime increased both locally and internationally. Many observers predicted the eminent downfall of the Cuban socialist regime. ${ }^{59}$ But the regime survived and relatively overcame some huge challenges. There was a form of resilience during the 1990s crisis as civil society emerged in areas traditionally occupied by the state, especially in the supplementary provision of services. Social relations and interactions were transformed via the emergence of new actors such as: Basic Units of Cooperative Production (UBPC), self-employed workers, those employed by foreign capital and foreign non-governmental organizations. ${ }^{60}$ However civil society did not replace the state which exclusively oversaw national security and social control. ${ }^{61}$ Confronted with socio-political and economic challenges in the post-Cold War era, there was a need to go beyond the socialist doctrine in order to address the crisis.

The resilience of the Cuban socialist regime was crucial in the era of capitalist dominance around the world. Having taken note of the massive popular frustration, the Cuban government repeatedly underwent series of economic resilience since socialist system seldom matched the international economic order. With the new international order that was capitalist inclined, the government became compelled to reinstitute the formerly banned touristic sector and personal entrepreneurship in Cuba. In a research work published in the Association for the Study of the Cuban Economy (ASCE), Suddaby presents the number of tourists rising from over 300,000 in 1988 to more than 1000,000 in $1996 .{ }^{62}$ From the 1990s, Castro's socialist regime was also compelled to adapt

\footnotetext{
58 Grint (2010), pp. 13-14

59 Wong-Diaz (2006), p. 1

60 Tulchin Joseph, Espina Prieto Mayra, Bobea, Lilian and Rafael Hernández (2005),

'Changes in Cuban Society since the Nineties'. Woodrow Wilson Center Report on the Americas, pp. 2-3

61 Ibid, p. 3

${ }^{62}$ Suddaby, Charles (1997), 'Cuba's Tourism Industry' in 'Cuba in Transition'. Association of the Study of Cuban Economy Volume 7, p. 124
} 
to a new situation as it 'decriminalised the dollar... legalised self-employment, decentralised the agricultural sector and boosted Cuba's tourist industry'.63 Despite the adoption of some capitalist policies, Fidel Castro remained expansively clung to the ideologies of the socialist revolution. He could use the period of crisis to 're-emerge' and as a result solidify his leadership. His charisma could play a mobilsing role towards redefining a collective goal.

Followers often share their leader's charisma by supporting his plan of actions and continue to expect outstanding results from the latter. ${ }^{64}$ The post-Cold War era created a new situation based on national and international reactions with regard to the leadership style portrayed by Fidel Castro. Some Cubans persistently believed in the revolution, others perceived it as a failure and the last set of Cubans aligned themselves without any conviction but compelled to do so. However, in times of crisis, followers willingly could make personal sacrifices for the ultimate achievement of a collective goal.65 Fidel Castro exercised a combination of referent and coercive power to pass across or instill the message among his followers. His mobilisation and communication abilities were remarkably identified during the 2001 Hurricane Michelle cyclone with the set joint efforts (popular participation, civil defense, meteorologists, and public administrators) that were able to save many lives during the disaster.66 In addition to the influence portrayed within national boundaries, Castro played some key roles on the international scene.

Although such opened Cuban interventions have more or less been inexistent in the post-Cold War era, Cuba had maintained strong relations with developing countries especially in the medical field. Meanwhile, many western democracies spearheaded vehemently by the U.S continued to attribute elements of dictatorship to the government of Cuba. The divided opinion about Fidel Castro's leadership has overtime been observed at both national and international levels. Most liberals have repeatedly connected political oppression to the leadership of the head of the Cuban revolution. Meanwhile, some key achievements in the sectors of health and education contributed to the building of some positive impressions around Fidel Castro's leadership.

\section{Assessing Castro's Leadership in Cuba}

\footnotetext{
63 Dolan, Brendan (2007), 'Cubanonomics: Mixed Economy in Cuba during the Special Period', Truthiness, Volume 1: 2007 Edition., p. 80

64 Grint (2010), p. 95

65 Ibid, p. 96

66 Cawthorne, A. (2001), 'Anxious Cuba braces for Hurricane Michelle', Reuters, 3 November, p. 1
} 
Assessing the Cuban revolution generally requires the measurement of leadership effectiveness and the outcomes produced. What has been the degree of effectiveness of the socialist system in Cuba? What are the records of achievements under Fidel Castro's rule? In answering these questions, there is need to understand how the socialist regime addressed challenges and whether or not people's expectations were met by the same regime. These interrogations have so far led to differences in appreciating the level of effectiveness and achievements of the socialist revolution in Cuba. During a 2007 politicointellectual debate pitting Alberto Montaner (a strong critic of Fidel Castro) and Ignacio Ramonet (a fervent supporter of Fidel Castro), a central question was posed: was Fidel Castro good for Cuba? Although these contrasted views do not speak for the entire Cuban community, they reflect existent divisive nature of Cuban's perception over Castro's leadership.

Alberto Montaner argued that Fidel Castro's initiated Communism has failed and led to abject poverty and enslavement of many Cubans. For him, Castro has put in place dictatorship where human rights are repressed with 300 individuals serving prison sentences for political reasons till 2007. He further described Fidel Castro's leadership as personalised and nontransferable. He concluded that Fidel Castro through communist dictatorship has failed to develop Cuba in a global world where democratic methods, rule of law, free market and private property are necessary tools for social, economic, political and human development. ${ }^{67}$ While on the other hand, Ignacio Ramonet presents Castro as a resilient and transformative leader who had effectively led Cuba despite serious local and international challenges. He thus described Castro's leadership as effective underpinned by numerous achievements. In supporting his view Ramonet highlighted economic growth in Cuba during the last decade of Castro's leadership: 'During the past 10 years, Cuba's average annual growth in gross domestic product was roughly 5 percent, among the highest in Latin America. In 2005, for example, the country saw growth rates of $11.8 \%{ }^{\prime}{ }^{68}$

The produced outcomes from the situation were mostly based on health and education. Education became very much accessible to everyone regardless of his or her financial background. The state bore the expenses for the training of medical practitioners which subsequently created significant access to health services. By 1989, the number of rural hospitals had increased to 64 against 1 prior to the 1959. Although facing difficulties to properly address the issue of potable water and sanitation, Cuba health indicator became comparable with

67 Foreign Policy, 'Was Castro Good for Cuba'? January/February 2007. www.ForeignPolicy.com., p. 56 
that of developed societies. ${ }^{69}$ According to the World Bank, the life expectancy in Cuba has risen from over 60 years in 1970 to 79.13 years in 2011.70 Achievements in health and education have been used by Fidel Castro sustain the rhetoric about an eminent total success.

Never the less, the politico-economic and social outcomes under Fidel Castro's leadership were nuanced. Most Cuban would have expected equal political opportunities via free elections, freedom of press, human rights consideration and higher income. The idea of a free society was not realised, views critical to that of the revolution were not welcomed by the government. Although a considerable number of Cubans remain financially unviable, the gap between the rich and the poor had diminished as compared to the pre-1959 era. There was a considerable egalitarian treatment on food, shelter, education and health prior to the end of the cold war. ${ }^{71}$ Based on the foregoing, it can be argued that despite some internal and external challenges, which confronted the Cuban state, the socialist system under Fidel Castro could accommodate certain elements of leadership effectiveness.

On the political angle, the personal leadership perspective was dominant to the extent that he was replaced at the helm of the Cuban Republic by his younger brother - Raoul Castro. Albeit the outcomes of Fidel Castro's leadership were not really proportional to popular demands, the process was effective as socialist laws were passed and strictly implemented in addressing the societal vices identified during the pre-revolutionary era. Maslow in his famous work tilted theory of human motivation argues that: 'A person who is lacking food, safety, love, and esteem would most probably hunger for food more strongly than for anything else'. ${ }^{72}$ Also with reference to Maslow's 'hierarchy of needs', leaders are prescribed to sort out followers' health and safety to enable the latter focus on higher needs. ${ }^{73}$ The socialist ideologies propagated by the leader of the Cuban revolution took into account such hierarchy of needs with the human centered approach. The health aspect in Cuba was addressed with extensive medical assistance provided by the government to various strata of the society. Despite some efforts on safety, the controversial nature of the Cuban government on human rights failed to achieve the political freedom the revolution promised the people from the commencement of its long fight against Batista's government.

\footnotetext{
69 Sixto, Felipe (2002), 'An Evaluation of Four decades of Cuban Healthcare'. Cuba in Transition. ASCE. 2002, p. 325

70 World Bank (2012), 'Life Expectancy in Cuba', p. 1

${ }^{71}$ Dolan (2007), p. 80

72 Maslow, Abraham (1943), 'A Theory of Human Motivation'. Psychological Review, Vol. 50, p. 373

73 Ibid, pp. 376-380
} 
Some analysts have however connected the imposed economic embargo to nuance the level of economic achievement. The socialist Cuba may not be a success story; still, it has portrayed significant elements of development which demonstrate the fact that many societal vices existing during the prerevolutionary era were addressed. The remarkable structural policy implementations covering health, education, agricultural and sport sectors, have significantly contributed to the human capacity building in the society. Also, the redistribution of Fidel Castro's family farm in line with the agrarian reform under the socialist regime tends to demonstrate that there was a strong political will despite some gaps in meeting expectations.

\section{Conclusion}

The emergence of Fidel Castro in Cuba was connected to the situation whereby Cubans yearned for a leader capable of addressing challenges akin to development crisis and despotic rule. The charisma exhibited by Fidel Castro during his civilian and armed struggles made of him a noticeable leader among many others. Despite some gaps, the resilient or adaptive leadership of Fidel Castro in Cuba has proven to be effective as it survived for almost half a century passing through Cold War and the Post-Cold War eras. Beside the considerable level of adaptability, the directional approach of Fidel Castro projected his image at many levels of decision making. The directional leadership was used by the leader to define the situation and consistently align the followers towards a common goal. In this case, the roles of institutions in this leadership process could overlap with the leaders' competencies. Besides the prevailing personal traits, relational tendencies were observed through transactional and transformational leadership styles. In the course of his leadership, Castro directly or indirectly played remarkable roles on the international scene. Above all, it should be noted that, the situation at the time in Cuba required the emergence of a leader mainly concerned with the welfare of the people. Fidel Castro was to a large extent the person of the situation as he initiated people centered policies added to his resilient abilities that could enable him re-emerge amidst compelling factors.

*Albert Poliquen Mbiatem is currently a PhD student at the University of Dschang in Cameroon. He is an alumnus of the African Leadership Centre, King's College London. 


\section{BIBLIOGRAPHY}

Alfonso, Haroldo (2001), 'Local Government and Economic and Social Change in Cuba', Focal Research Forum on Cuba

Balthazard, Pierre; Waldman, David and Warren, John (2009), 'Predictors of the Emergence of Transformational Leadership in Virtual Decision Teams', The Leadership Quarterly, Vol. 20, pp. 651-663

Bass, Bernard (2008), The Bass Handbook of Leadership. Theory, Research, and Managerial Applications. Fourth Edition, (Free Press)

Bennett, William (2011), The Book of Man: Readings on the Path to Manhood (Nashville TN: Thomas Nelson Publishers)

Bourne, Peter (1986), Fidel: A Biography of Fidel Castro (New York City: Dodd, Mead \& Company)

Bunck, Julie (1994), Fidel Castro and the Quest for a Revolutionary Culture in Cuba (The Pennsylvania State University Press)

Burns, James (1978), Leadership (Harper \& Row, Publishers)

Carbonell, Brenden (2009), 'Cuban Corporatism: Batista's Three-year Plan and a Nation Betrayed in eds cuba in transition'. ASCE 2009

Castro, Fidel (1953), 'History Will Absolve Me'. Excerpts from his own defense, delivered at his trial, October 1953

Castro, Fidel (1981), 'Defending Cuba's Socialist Revolution'. Fidel Castro Speeches. Vol. 2. Ed. Michael Taber (New York: Pathfinder)

Cawthorne, A. (2001), 'Anxious Cuba braces for Hurricane Michelle', Reuters 3 November

Dominguez, Jorge (1998), 'Batista in Cuba' in Chehabi, H. and linz, J., eds Sultanistic Regimes (The Johns Hopkins University Press), pp. 113-131

Coltman, Leycester (2003), The Real Fidel Castro (New Haven and London: Yale University Press) 
Delgado, Fernando (1999), 'The Rhetoric of Fidel Castro: Ideographs in the Service of Revolutionaries'. Howard Journal of Communication 10 (1999): 1-14

Dolan, Brendan (2007), 'Cubanonomics: Mixed Economy in Cuba during the Special Period' Truthiness Volume 1: 2007 Edition

Foreign Policy, 'Was Castro Good for Cuba'? January/February 2007. www.ForeignPolicy.com

Grint, Keith (2010), Leadership: A Very Short Introduction (Oxford University Press Inc., New York)

Guevara, Ernest (2006), Reminiscences of the Cuban Revolutionary War (Harper Perennial)

Hollander, Paul (2002), Discontents: postmodern and postcommunist (New Brunswick: Transaction Publishers)

Hugh, Thomas (1986), The Cuban Revolution (Weidenfeld and Nicolson. London)

Kessler, Stephanie (1990), 'Cuba's Involvement in Angola and Ethiopia: A Question of Autonomy in Relationship with the Soviet Union'. Thesis, Dember 1990. Naval Postgraduate School Monterey, California

Kice, Brent (2008), 'From the Mountains to the Podium: the Rhetoric of Fidel Castro'. PhD Thesis Submitted to the Louisiana State University

Latell, Brian (2006), 'Fidel Castro and the Media’. The Latell Report, Cuba Transition Project (CTP) at the University of Miami's Institute for Cuban and Cuban-American Studies (ICCAS), May 2006

Martin, Lionel (1978), The Early Fidel: Roots of Castro's Communism. Secaucus (NJ: Lyle Stuart)

Masciulli, Joseph, Molchanov, Mikhail. and Knight, Andy (2009), 'Political Leadership in Context, in J. Masciulli, M. Molchanov and W. Knight, eds., The Ashgate Research Companion to Political Leadership (Ashgate Publishing Limited, England), pp. 3-30

Maslow, Abraham (1943), 'A Theory of Human Motivation'. Psychological Review, Vol. 50, pp. 370-396 
Miller, Ivor (2000), 'Religious Symbolism in Cuban Political Performance', The Drama Review, Volume 44, Number 2 (T 166), Summer2000, pp. 30-55

Mitchell, Orenstein (2009) 'Cuban Political System: More than Just Castro', Comparative National Systems

New York Times (1962) 'Letter from President Kennedy to Chairman Kruschev', Oct 27, 1962.

Northouse, Peter (2013), Leadership: Theory and Practice. Sixth Edition (Sage Publication)

Ojito, Mirta (2005), Finding Manana: A Memoir of a Cuban Exodus (NY: Penguin)

Olson, James (2000), Historical Dictionary of the 1950s (Greenwood Publishing Group)

Pickering, Ron (1978), 'Cuba' in Sport Under Communism Ed. James Riordan (London: C Hurst \& Co), pp. 142-174

Prevost, Gary (2007), 'Fidel Castro and the Cuban Revolution'. Headwaters: The Faculty Journal of the College of Saint Benedict and Saint John's University: Vol. 24, pp. 19-33

Quirk, Robert (1993), Fidel Castro (New York and London: W.W. Norton \& Company)

Rice, Donald (1987) 'Castro's Early Rhetoric: The Myth of the Savior' in Charles Kneupper, ed., Visions of Rhetoric: History, Theory and Criticism (Arlington, TX: Rhetoric Society of America)

Schneider, Ehrhart and Goktepe, Janet (1983), 'Issues in emergent leadership: The contingency model of leadership, leader sex, leader behavior'. In H. H. Blumberg, A. P.Hare, V. Kent, \& M. F. Davies, eds., Small groups and social interaction (Chicester, England: John Wiley), pp. 413-421

Sixto, Felipe (2002), 'An Evaluation of Four decades of Cuban Healthcare', Cuba in Transition. ASCE. 2002

Slee, Chris (2008), Cuba: How the Workers and Peasants Made the Revolution (Resistance Books Australia) 
Sternberg Robert, Antonakis John and Cianciolo Anna (2004), The Nature of Leadership (Thousand Oaks, CA: SAGE)

Suddaby, Charles (1997), 'Cuba's Tourism Industry' in 'Cuba in Transition'. Association of the Study of Cuban Economy Volume 7, 1997

The Constitution of the Republic of Cuba, 1976

The Huffington Post (2013), 'Nelson Mandela, Fidel Castro: A Relationship Built On Mutual Admiration'. By Hirania Luzardo Posted: 06/27/2013

Treto, Carlos (2009), 'Continuity and political change in Cuba'. University of Havana

Tulchin Joseph, Espina Prieto Mayra, Bobea,Lilian and Rafael Hernández (2005), 'Changes in Cuban Society since the Nineties'. Woodrow Wilson Center Report on the Americas

Turska-Kawa, Agnieszka (2013), 'Reactive Political leadership'. Political Preferences, No 4/2013, University of Selesia, Poland

Weber, Max (1978), Economy and Society (Berkeley: University of California Press)

Wong-Dias, Francisco (2006). 'Castro's Cuba: Quo Vadis'. Strategic Studies Institute (SSI) Publications

World Bank (2012), 'Life Expectancy in Cuba' 